\title{
Analysis of polymorphisms, promoter methylation, and mRNA expression profile of maternal and placental P53 and P21 genes in preeclamptic and normotensive pregnant women
}

\author{
Mahdiyeh Harati-Sadegh ${ }^{1}$, Leila Kohan², Batool Teimoori ${ }^{3}$, Mehrnaz Mehrabani ${ }^{4}$ and Saeedeh Salimi ${ }^{5,6^{*}}$
}

\begin{abstract}
Background: Preeclampsia (PE), as a multisystem disorder, is associated with maternal hypertension and proteinuria. Apoptosis seems to be involved in the pathophysiology of $\mathrm{PE}$, although its precise pathogenic mechanisms are not well established. In this study, we aimed to identify the association between maternal TP53rs1042522, P21-rs1801270, and P21-rs1059234 polymorphisms and PE. In addition, we examined the effects of promoter methylation and TP53 and P21 polymorphisms on placental mRNA expression in PE women.

Methods: The blood of 226 PE women and 228 normotensive pregnant women was examined in this study. In addition, the placentas were genotyped in $109 \mathrm{PE}$ and 112 control women. The methylation status was assessed by a methylation-specific PCR assay, while mRNA expression was examined via Quantitative Real Time PCR.

Results: The maternal and placental P21-rs1801270 CA genotype had a significant association with the reduced risk of PE. In the dominant, recessive, and allelic models, maternal/placental P21-rs1059234 polymorphism had no statistically significant association with the risk of PE. On the other hand, the reduced risk of PE was associated with maternal, but not placental TP53-rs1042522 polymorphism in the dominant and recessive models. The maternal and placental P21-rs 1801270 polymorphism was associated with PE risk. The maternal P21 $\mathrm{T}_{\text {rs } 1059234} \mathrm{C}_{\mathrm{rs} 1801270}$ haplotype was associated with 3.4-fold increase in PE risk, However the maternal P21 $\mathrm{T}_{\mathrm{rs} 1059234} \mathrm{~A}_{\mathrm{rs}} 1801270$ haplotype and placental $\mathrm{C}_{\mathrm{rs} 1059234 \mathrm{C}} \mathrm{A}_{\mathrm{rs} 1801270}$ haplotype led to 0.5 and 0.4-fold decrease in PE risk, respectively. PE women showed 5.6 times higher levels of placental mRNA expression of TP53 gene, although it was not associated with rs 1042522 polymorphism. The relative placental mRNA expression of P21 gene was 0.2 in PE women. It was also 2.4 times higher in individuals with rs1801270CA genotype than those with AA genotype. The hyper-methylation of P21 and TP53 genes in the promoter region was associated with a 3.4-fold and 3-fold increase in PE risk, respectively. However, no association was found between P21 and TP53 mRNA expression and promoter methylation.

Conclusion: In conclusion, P21-rs1801270 and TP53-rs1042522 polymorphisms were involved in reduced risk of PE. P21-rs1801270 was associated with decreased P21 mRNA expression. The hyper-methylation of P21 and TP53 genes in the promoter region was associated with a higher PE risk.
\end{abstract}

Keywords: P21, P53, Placenta, Polymorphism, Preeclampsia, Methylation

\footnotetext{
* Correspondence: sasalimi@yahoo.com

${ }^{5}$ Department of Clinical Biochemistry, School of Medicine, Zahedan University of Medical Sciences, Zahedan, Iran

${ }^{6}$ Cellular and Molecular Research Center, Zahedan University of Medical Sciences, Zahedan, Iran

Full list of author information is available at the end of the article
}

(c) The Author(s). 2019 Open Access This article is distributed under the terms of the Creative Commons Attribution 4.0 International License (http://creativecommons.org/licenses/by/4.0/), which permits unrestricted use, distribution, and reproduction in any medium, provided you give appropriate credit to the original author(s) and the source, provide a link to the Creative Commons license, and indicate if changes were made. The Creative Commons Public Domain Dedication waiver (http://creativecommons.org/publicdomain/zero/1.0/) applies to the data made available in this article, unless otherwise stated. 


\section{Background}

Preeclampsia (PE) is a multisystem disorder, characterized by maternal hypertension and proteinuria. PE has been detected in 3-5\% of all pregnancies around the world $[1,2]$. This disorder may progress to eclampsia (convulsive form) due to late presentation, delayed diagnosis, and delayed treatment. It is therefore necessary to identify reliable hallmarks for early diagnosis of PE and develop efficient treatment strategies [3]. The precise pathogenic mechanisms underlying PE are still undetermined. Nevertheless, some important factors in PE development involve insufficient development of the placenta, immune maladaptation, oxidative stress, thrombosis, and placental ischemia. In addition, there are genetic factors in these components, which contribute to these pathogenic changes $[4,5]$. In the trophoblast life cycle, normal proliferation and apoptosis are considered necessary. Aberrant cell turnover occurs in PE pregnancies, leading to increased apoptosis in placental trophoblasts [6]. The placental size and uteroplacental blood flow are limited due to abnormal cytotrophoblast cell differentiation during spiral artery invasion in uterine; therefore, the needs of the growing fetus are not met. In addition, placental hypoxia can be led to increased apoptosis in syncytiotrophoblast cells and necrosis [7]. The intracellular mechanisms of apoptosis in the PE placenta remain unknown [8]. TP53 as a tumor suppressor contributes to the progression of cell cycle and apoptosis [9]. P53 protein, as a major transcription factor, is involved in the regulation of cell apoptosis, growth arrest, and DNA repair under cell stress conditions. To activate downstream target genes, p53 is phosphorylated and acetylated at different sites [10]. During complicated pregnancies, the level of p53 increases in the placenta, highlighting its role in the apoptosis of trophoblasts [11]. Downstream transcription of elements contributing to cell apoptosis and cycle arrest (e.g., p21) is promoted by increased level of p53 [8]. The TP53 gene on chromosome 17 encodes a $53-\mathrm{kDa}$ protein composed of 393 amino acids. Functional effects have been attributed to various single nucleotide polymorphisms (SNPs) of TP53 gene. At codon 72, a G > C substitution characterizes the TP53 gene polymorphism (P72R, rs1042522), which is found in the transactivation domain of the p53 protein with possible effects on the protein activity [12]. P21 (p21Cip1), as an important cell cycle regulator in G1 and S phases, is involved in the pathogenesis of various diseases [13]. Overall, rs1801270 (C98A), as the most common P21 gene polymorphism, is a $\mathrm{C}>\mathrm{A}$ substitution at codon 31 of the $\mathrm{P} 21$ protein. Accordingly, DNA binding of zinc finger motif and P21 expression may alter. In addition, rs1059234 (C70T) is another P21 polymorphism, which is located downstream the stop codon in the $3^{\prime}$-untranslated region.
This site is involved in cell proliferation, differentiation, and tumor suppression [14]. Several studies have indicated both genes and apoptotic pathways are important in the regulation on $\mathrm{PE}[15,16]$. However, no studies have examined the association of P21 gene polymorphisms with PE development. In addition, the association between the TP53 polymorphisms and PE has been less highlighted [17]. On the other hand, some studies have confirmed a relationship between methylation of various genes and PE [2, 18]. These results suggest that epigenetic modifications such as DNA methylation affect gene expression and can act as susceptibility factors in various diseases, including PE. DNA methylation as a complex process depends on environmental factors and genomic background [19]. Although the pathogenesis of $\mathrm{PE}$ is closely associated with the methylation status of the relevant genes [20], the association between placental promoter methylation of P21/ TP53 gene and PE risk remains unexamined. In the present study, we examined the association of maternal and placental TP53 (rs1042522) and P21 (rs1801270 and rs1059234) gene polymorphisms with the risk of PE development. Then, we examined the effects of placental P21-rs1801270, P21-rs1059234, and TP53-rs1042522 polymorphisms and placental DNA methylation of P21 /TP53 gene (promoter regions) on P21/TP53 mRNA expression.

\section{Materials and methods Subjects}

In this study, a total of 228 healthy pregnant women and 226 PE women were recruited from Ali-ebn-Abi Taleb Hospital, affiliated to Zahedan University of Medical Sciences. PE was characterized by hypertension and proteinuria. Proteinuria was defined as $\geq 0.3 \mathrm{~g} / 24 \mathrm{~h}$ or $\geq+1$ protein on a urine dipstick after the 20th gestational week, and hypertension was described as systolic blood pressure $(\mathrm{SBP}) \geq 140 \mathrm{mmHg}$ or diastolic blood pressure $(\mathrm{DBP}) \geq 90 \mathrm{mmHg}$ on two or more assessments (within at least six-hour intervals) [21]. Absence of proteinuria or hypertension and no increase in blood pressure were the study inclusion criteria for control group. On the other hand, autoimmune diseases, renal disorders, chronic hypertension, cancer, collagen vascular disorders, and thrombosis were among the study exclusion criteria. Following delivery, the placentas of 112 normotensive women and $109 \mathrm{PE}$ women, as well as the blood samples of all study participants were collected.

\section{Sample preparation}

After collecting peripheral blood samples $(2 \mathrm{~mL})$ from mothers, they were kept in a freezer at $-20^{\circ} \mathrm{C}$. Placental tissues were collected after childbirth. To remove fetal and maternal blood, phosphate-buffered saline was used 
for washing the tissue samples at $4{ }^{\circ} \mathrm{C}$. The tissue samples were kept at $-80^{\circ} \mathrm{C}$ for the extraction of DNA and RNA.

\section{Genetic analysis}

The salting-out method was used for extracting genomic DNA from peripheral blood samples, treated with EDTA. A DNA extraction kit (DynaBio, Takapoozist, Iran) was also used to extract DNA from placental tissues according to manufacturer's instruction. The PCR-RFLP assay was carried out for the detection of TP53 (rs1042522) and P21 (rs1801270 and rs1059234) polymorphisms, as described by Yaghmaei et al. [12] and Salimi et al. [14], respectively. The annealing temperature, primer sequences, and fragment size are presented in Table 1 . To confirm genotyping quality, we carried out the randomly repeated genotyping for about $30 \%$ of the samples and the findings were in accordance to the preceding genotyping results.

\section{DNA bisulfite conversion and methylation-specific PCR}

An EpiTect Bisulfite kit (Qiagen, Germany) was used for treating the placental DNA of $109 \mathrm{PE}$ and 112 control women with sodium bisulfite. The methylation-specific PCR (MSP) assay was performed to analyze the alleles (methylated and unmethylated); Table 1 presents the primers for the promoter regions of P21 and TP53 genes $[22,23]$. For MSP amplification, a final volume of $15 \mu \mathrm{L}$ containing $5 \mu \mathrm{L}$ of deionized water, $7 \mu$ of hot-start PCR master mix, $1 \mu \mathrm{L}$ of template bisulfite DNA $(\sim 100 \mathrm{ng} / \mu \mathrm{L})$, and $1 \mu \mathrm{L}$ of every primer, was used. The thermocycling conditions for the PCR were as follows: 35 cycles of PCR, including $35 \mathrm{~s}$ of denaturation at $95^{\circ} \mathrm{C}, 35 \mathrm{~s}$ of annealing at $60^{\circ} \mathrm{C}, 35 \mathrm{~s}$ of extension at $72^{\circ} \mathrm{C}$, and a final $10-\mathrm{min}$ extension for all primer sets at $72^{\circ} \mathrm{C}$ (Fig. 1).

\section{Real-time PCR assay}

To isolate total RNA from the placenta, we used RNXPlus (Sinaclon, Tehran, Iran). Moreover, PrimeScript 1st strand cDNA synthesis kit (Takara Bio, Shiga, Japan) was used to generate cDNA according to the manufacturer's instructions. An ABI PRISM 7500 RT-PCR system (Applied Biosystems) with SYBR Green was used to evaluate mRNA expression. For amplification, a reaction mixture $(20 \mu \mathrm{l})$ of SYBR Green/high ROX (10 $\mu \mathrm{l}$; Amplicon), $2 \mu \mathrm{l}$ of cDNA solution, $7 \mu \mathrm{l}$ of nuclease-free water, and 10 pmol of each primer [23-25] was used. Analysis of each sample was performed in triplicate. To determine the relative expression of mRNA in the target genes, the $2^{-\Delta \Delta \mathrm{Ct}}$ method was applied, then, the expression levels were normalized to a housekeeping gene; $\Delta \mathrm{Ct}$ was the difference between $\beta$-actin (control) and P21/TP53 genes.

\section{Statistical analysis}

To compare the clinical parameters between the groups, Chi square was used. Using logistic regression analysis, the relationship between case-control status and genetic variants was also determined after adjustment for age, BMI and ethnicity. To determine the significant allelic and genotypic associations, the odds ratios (ORs) were measured at a 95\% CI (confidence interval). The effects of polymorphism and methylation

Table 1 The primer sequences, annealing temperature and fragment sizes for molecular analysis

\begin{tabular}{|c|c|c|c|c|}
\hline & Method & Primer Sequence $5^{\prime} \rightarrow 3^{\prime}$ & PCR Product (bp) & $\mathrm{Tm}{ }^{\circ} \mathrm{C}$ \\
\hline P21-rs1059234 & PCR-RFLPa & $\begin{array}{l}\text { Forward: CCCAGGGAAGGGTGTCCTG } \\
\text { Reverse: GGGCGGCCAGGGTATGTAC }\end{array}$ & 298 & 64 \\
\hline P21-rs1801270 & PCR-RFLP & $\begin{array}{l}\text { Forward: GTCAGAACCGGCTGGGGATG } \\
\text { Reverse: CTCCTCCCAACTCATCCCGG }\end{array}$ & 272 & 64 \\
\hline TP53-rs1042522 & PCR-RFLP & $\begin{array}{l}\text { Forward: GTCCCAAGCAATGGATGAT } \\
\text { Reverse: CAAAAGCCAAGGAATACACG }\end{array}$ & 551 & 61 \\
\hline \multirow[t]{2}{*}{$\begin{array}{l}\text { P21 } \\
\text { promoter region }\end{array}$} & $M S P^{b}$ & $\begin{array}{l}\text { FM: TACGCGAGGTTTCGGGATC } \\
\text { RM: CCCTAATATACAACCGCCCCG }\end{array}$ & 174 & 60 \\
\hline & & $\begin{array}{l}\text { FU: GGATTGGTTGGTTGTTGGAATTा } \\
\text { RU: ACAACCCTAATATACAACCACCCCA }\end{array}$ & 164 & \\
\hline \multirow[t]{2}{*}{$\begin{array}{l}\text { P53 } \\
\text { promoter region }\end{array}$} & MSP & $\begin{array}{l}\text { FM: GTAGTTTGAACGTITTATTTGGC } \\
\text { RM: CCTACTACGCCCTCTACAAACG }\end{array}$ & 115 & 60 \\
\hline & & $\begin{array}{l}\text { FU: GTAGTTTGAATGTITTATTITGGT } \\
\text { RU: CCTACTACACCCTCTACAAACA }\end{array}$ & 115 & \\
\hline P21 & Real-time PCR & $\begin{array}{l}\text { Forward: GCTCTGCTGCAGGGGACAGC } \\
\text { Reverse: TCTGCCGCCGTITTCGACCC }\end{array}$ & 136 & 60 \\
\hline P53 & Real-time PCR & $\begin{array}{l}\text { Forward: GAGCTGAATGAGGCCTTGGA } \\
\text { Reverse: CTGAGTCAGGCCCTTCTGTCTT }\end{array}$ & 151 & 60 \\
\hline$\beta$-Actin & Real-time PCR & $\begin{array}{l}\text { Forward: CCTGGCACCCAGCACAAT } \\
\text { Reverse: GCCGATCCACACGGAGTACT }\end{array}$ & 70 & 60 \\
\hline
\end{tabular}

a Polymerase chain reaction-restriction fragment length polymorphism ${ }^{\mathrm{b}}$ Methylation Specific PCR 


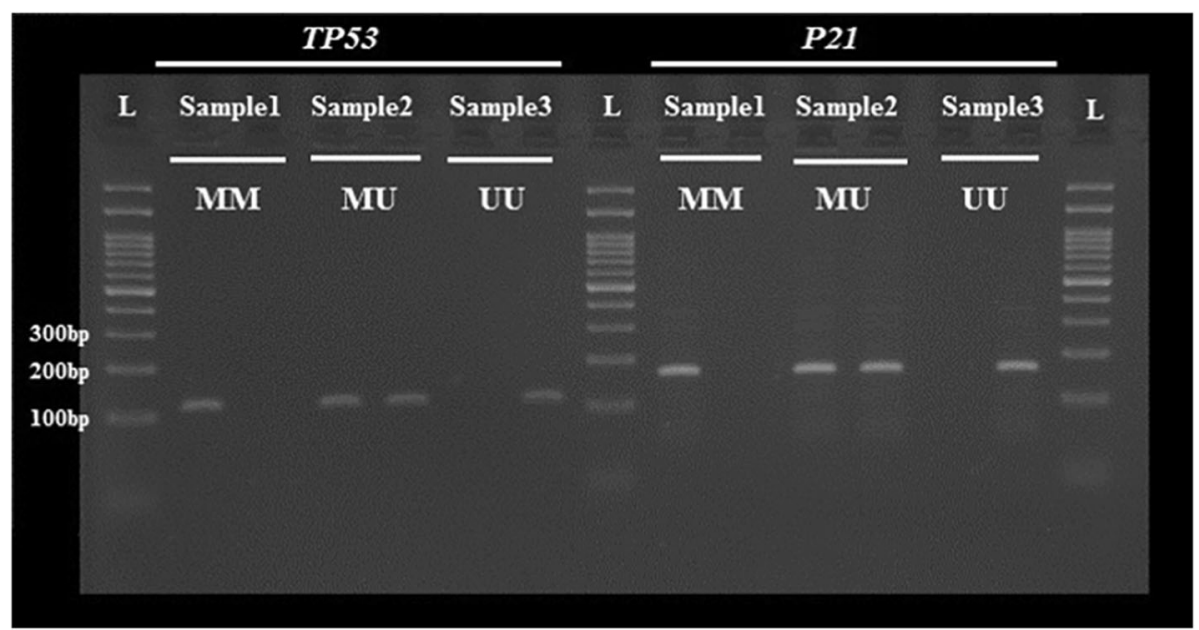

Fig. 1 Methylation specific PCR analysis of P21 and TP53 promoter regions from bisulfite-treated DNA

on mRNA expression were examined by the One-Way ANOVA test. Haplotype analysis was conducted using online SHEsisPlus software [26]. The Posthoc Bonferroni correction was performed to confirm the findings. To analyze data, SPSS version 20.0 was used at a significance level of 0.05 .

\section{Results}

\section{Population characteristics}

Table 2 presents the clinical and demographic data of 454 pregnant women (228 normotensive women and 226 women with $\mathrm{PE}$ ). The mean of maternal age and BMI were similar between two groups. The ethnicity did not differ between PE and control women. The PE group had a significantly lower gestational age and birth weight, while SBP, DBP and the frequency of primiparity were significantly higher.

Table 2 Demographic characteristics of PE women and controls

\begin{tabular}{llll}
\hline Variable & $\begin{array}{l}\text { Controls } \\
n=228\end{array}$ & PE $n=226$ & P-value \\
\hline Maternal age(mean $\pm \mathrm{SD}$, years) & $28.3 \pm 6.4$ & $27.5 \pm 6.2$ & 0.2 \\
BMI(kg/m2) & $26.5 \pm 3.1$ & $27.03 \pm 3.7$ & 0.1 \\
Gestation age(mean $\pm \mathrm{SD}$, days) & $273 \pm 18$ & $254 \pm 24$ & $<0.0001$ \\
Birth weight (mean $\pm \mathrm{SD}, \mathrm{g})$ & $3079 \pm 410$ & $2873 \pm 498$ & $<0.0001$ \\
SBP(mean $\pm \mathrm{SD}, \mathrm{mmHg})$ & $103 \pm 13$ & $151 \pm 19$ & $<0.0001$ \\
DBP(mean $\pm \mathrm{SD}, \mathrm{mmHg})$ & $68 \pm 9.2$ & $96 \pm 12.7$ & $<0.0001$ \\
Primiparity, $\mathrm{n}(\%)$ & $60(26.3)$ & $102(45.1)$ & $<0.0001$ \\
Ethnicity & & & \\
Fars & $100(43.9)$ & $104(46)$ & 0.4 \\
Balooch & $128(56.1)$ & $122(54)$ & \\
\hline SD: Standard Devation & & & \\
\hline
\end{tabular}

SD: Standard Deviation

\section{Maternal P21 and TP53 polymorphisms and PE}

The genotypic and allelic frequencies of P21 and TP53 polymorphisms in the maternal blood are shown in Table 3. The binary logistic regression model regarding the effects of genotypes on the risk of PE showed the following results:

There was no association between PE risk and P21rs1059234 polymorphism in the dominant, recessive, and allelic models. The frequency of P21-rs1801270 CA genotype was significantly lower in the PE group, and this genotype could protect against $\mathrm{PE}$ susceptibility (OR $=0.3$, 95\% CI: 0.2-0.6, $P=0.0002)$. Moreover, in the dominant and allelic models, $P 21$-rs1801270 reduced PE risk $(\mathrm{OR}=0.4,95 \% \mathrm{CI}$ : $0.3-0.7, P=0.002$; $\mathrm{OR}=0.6,95 \%$ CI: $0.4-0.9, P=0.03$; respectively). The frequencies of TP53-rs1042522 GC and CC genotypes were significantly lower in the PE group than those of the controls and were associated with a decline in PE risk $(\mathrm{OR}=0.5$, 95\% CI: $0.3-0.9, P=0.01$; OR $=0.4,95 \%$ CI: $0.2-0.6, P=$ 0.0003). Additionally, a significant relationship was found between TP53-rs1042522 and PE risk reduction in the dominant, recessive, and allelic models $(\mathrm{OR}=0.5$, 95\% CI: $0.3-0.7, P=0.001 ; \mathrm{OR}=0.6,95 \% \mathrm{CI}: 0.4-0.9$, $P=0.007 ; \mathrm{OR}=0.6,95 \% \mathrm{CI}: 0.5-0.8, P=0.0001)$.

\section{Placental P21 and TP53 polymorphisms and PE}

As shown in Table 4, no association was found between the risk of PE and placental P21-rs1059234 polymorphism. However, the CA genotype of P21-rs1801270 frequency was significantly lower in the placenta of $\mathrm{PE}$ patients and was associated with PE risk reduction $(\mathrm{OR}=$ 0.4, 95\% CI: $0.2-0.8, P=0.013)$. Moreover, a significant relationship was found between P21-rs1801270 and PE risk reduction in the dominant model $(\mathrm{OR}=0.5,95 \% \mathrm{CI}$ : $0.2-0.9, P=0.034)$. In the recessive and allelic models, 
Table 3 The frequency of alleles and genotypes of maternal P21-rs1059234, P21-rs1801270 and TP53-rs1042522 polymorphisms in PE women and controls

\begin{tabular}{|c|c|c|c|c|c|}
\hline & $\mathrm{PE}(n=226)$ & Control $(n=228)$ & $P$-value & OR(95\% CI) & BC P-value \\
\hline \multicolumn{6}{|l|}{ P21-rs1059234 } \\
\hline CC, n(\%) & $199(88)$ & $199(87)$ & - & 1 & \\
\hline$C T, n(\%)$ & $22(10)$ & $28(12)$ & 0.43 & $0.7(0.4-1.4)$ & 0.44 \\
\hline T, n(\%) & $5(2)$ & $1(1)$ & 0.14 & $5(0.6-43.2)$ & 0.11 \\
\hline Dominant (CT + TT vs. CC) & & & 0.8 & $0.9(0.5-1.6)$ & 0.8 \\
\hline Recessive (TT vs. CC + CT) & & & 0.14 & $5(0.6-44.3)$ & 0.11 \\
\hline C, n(\%) & $420(93)$ & $426(93)$ & & 1 & \\
\hline $\mathrm{T}, \mathrm{n}(\%)$ & $32(7)$ & $30(7)$ & 0.8 & $1.1(0.6-1.8)$ & - \\
\hline \multicolumn{6}{|l|}{ P21-rs1801270 } \\
\hline CC, n(\%) & $200(89)$ & $177(78)$ & - & 1 & \\
\hline CA, n(\%) & $19(8)$ & $49(21)$ & 0.0002 & $0.3(0.2-0.6)$ & 0.0001 \\
\hline$A A, n(\%)$ & $7(3)$ & $2(1)$ & 0.16 & $3.1(0.6-15.1)$ & 0.14 \\
\hline Dominant (CA + AA vs. CC) & & & 0.002 & $0.4(0.3-0.7)$ & 0.002 \\
\hline Recessive (AA vs. CC + CA) & & & 0.11 & $3.6(0.7-17.6)$ & 0.09 \\
\hline C, n(\%) & 419 (93) & $403(88)$ & & 1 & \\
\hline$A, n(\%)$ & $33(7)$ & $53(12)$ & 0.03 & $0.6(0.4-0.9)$ & - \\
\hline \multicolumn{6}{|l|}{ TP53-rs1042522 } \\
\hline GG, n(\%) & $65(29)$ & $36(16)$ & - & 1 & \\
\hline GC, n(\%) & $98(43)$ & $101(44)$ & 0.012 & $0.5(0.3-0.9)$ & 0.012 \\
\hline$C C, n(\%)$ & $63(28)$ & $91(40)$ & 0.0003 & $0.4(0.2-0.6)$ & 0.0002 \\
\hline Dominant (GC + CC vs. GG) & & & 0.001 & $0.5(0.3-0.7)$ & 0.001 \\
\hline Recessive (CC vs. GG + GC) & & & 0.007 & $0.6(0.4-0.9)$ & 0.007 \\
\hline $\mathrm{G}, \mathrm{n}(\%)$ & $228(51)$ & $173(38)$ & & 1 & \\
\hline C, n(\%) & $224(49)$ & $283(62)$ & 0.0001 & $0.6(0.5-0.8)$ & - \\
\hline
\end{tabular}

BC $P$-value, Bonferroni corrected $P$-value

the placental P21-rs1801270 polymorphism had no association with PE. Based on the findings, the frequency of CC genotype in the placental TP53-rs1042522 polymorphism was lower in the PE group compared to controls, but the difference was marginally non-significant $(P=0.051)$. However, a significant relationship was found between TP53-rs1042522 and PE risk reduction in the allelic model (OR $=0.7$, OR: $0.4-1, P=0.03)$.

\section{Haplotype analysis and linkage disequilibrium of $P 21$ gene}

Table 5 presents four haplotypes of maternal C98A (rs1801270) and C70T (rs1059234) polymorphisms, including two alleles from each polymorphism. In both groups, $C_{\text {rs1059234 }} C_{\text {rs1801270 }}$ was the most common haplotype. According to the haplotype analysis, $\mathrm{T}_{\mathrm{rs} 1059234 \mathrm{C}} \mathrm{C}_{\mathrm{rs} 1801270}$ haplotype was significantly higher in PE women, which was associated with a 3.4-fold increase in $\mathrm{PE}$ risk $(\mathrm{OR}=3.4,95 \% \mathrm{CI}$ : 1.4-8.2, $P=$ 0.005). Moreover, $\mathrm{T}_{\mathrm{rs} 1059234 \mathrm{C}} \mathrm{A}_{\mathrm{rs} 1801270}$ haplotype was significantly higher in healthy women, which was associated with a decreased in PE risk to 0.5-fold. $(\mathrm{OR}=0.5$, 95\% CI: $0.2-1, P=0.03)$. The linkage disequilibrium was determined for $P 21$ polymorphisms $\left(D^{\prime}=0.31, r^{2}=0.09\right.$ in the PE group vs. $\mathrm{D}^{\prime}=0.73, \mathrm{r}^{2}=0.27$ in the controls).

Placental P21-rs1059234 and P21-rs1801270 haplotypes analysis showed a significant association between $\mathrm{C}_{\mathrm{rs} 1059234 \mathrm{C}} \mathrm{A}$ rs1801270 haplotype and PE risk reduction (OR = 0.4, 95\%CI: 0.2-0.9, $P=0.03)$ (Table 6).

\section{DNA methylation of placental P21/TP53 gene}

Table 7 presents the promoter DNA methylation of placental P21 and TP53 genes in the two groups. The higher frequency of partially methylated status (UM) in $P 21$ promoter region and high frequency of hyper-methylated status (MM) in TP53 promoter region was reported in the $\mathrm{PE}$ group, which was associated with a higher PE risk $(\mathrm{OR}=$ $2.9, \quad 95 \% \mathrm{CI}=1.1-7.2, \quad \mathrm{P}=0.026 ; \quad \mathrm{OR}=9.7, \quad 95 \% \mathrm{CI}=1.2$ $79.2, P=0.034$; respectively). In addition, the frequency of partially and hyper-methylated status (UM + MM) in P21 
Table 4 The frequency of alleles and genotypes of placental P21-rs1059234, P21-rs1801270 and TP53-rs1042522 polymorphisms in PE women and controls

\begin{tabular}{|c|c|c|c|c|c|}
\hline & $\begin{array}{l}\mathrm{PE} \\
(n=109)\end{array}$ & $\begin{array}{l}\text { Control } \\
(n=112)\end{array}$ & $P$-value & OR(95\% Cl) & $\begin{array}{l}\mathrm{BC} \\
P \text {-value }\end{array}$ \\
\hline \multicolumn{6}{|l|}{ P21-rs1059234 } \\
\hline CC, n(\%) & $89(81.7)$ & 97 (86.6) & - & 1 & \\
\hline$C T, n(\%)$ & $17(15.6)$ & $13(11.6)$ & 0.37 & $1.4(0.6-3.1)$ & 0.38 \\
\hline T, n(\%) & $3(2.8)$ & $2(1.8)$ & 0.60 & $1.6(0.3-10)$ & 0.59 \\
\hline Dominant (CT + TT vs. CC) & & & 0.32 & $1.4(0.7-3)$ & 0.31 \\
\hline Recessive (TT vs. CC + CT) & & & 0.63 & $1.6(0.2-9.5)$ & 0.62 \\
\hline C, n(\%) & $195(89.5)$ & $207(92.4)$ & - & 1 & \\
\hline $\mathrm{T}, \mathrm{n}(\%)$ & $23(10.5)$ & $17(7.6)$ & 0.3 & $1.4(0.7-2.8)$ & - \\
\hline \multicolumn{6}{|l|}{ P21-rs1801270 } \\
\hline CC, n(\%) & $95(87.2)$ & 85 (75.9) & - & 1 & \\
\hline$C A, n(\%)$ & $11(10.1)$ & $26(23.2)$ & 0.013 & $0.4(0.2-0.8)$ & 0.010 \\
\hline$A A, n(\%)$ & $3(2.8)$ & $1(0.9)$ & 0.40 & $2.7(0.3-26.3)$ & 0.38 \\
\hline Dominant (CA + AA vs. CC) & & & 0.034 & $0.5(0.2-0.9)$ & 0.031 \\
\hline Recessive (AA vs. CC + CA) & & & 0.33 & $3.1(0.3-30.7)$ & 0.30 \\
\hline C, n(\%) & $201(92)$ & $196(87.5)$ & - & 1 & \\
\hline $\mathrm{A}, \mathrm{n}(\%)$ & $17(8)$ & $28(12.5)$ & 0.1 & $0.6(0.3-1.1)$ & - \\
\hline \multicolumn{6}{|l|}{ TP53-rs1042522 } \\
\hline GG, n(\%) & $31(28.4)$ & $21(18.8)$ & - & 1 & \\
\hline GC, n(\%) & $45(41.3)$ & $45(40.2)$ & 0.27 & $0.7(0.4-1.4)$ & 0.27 \\
\hline CC, n(\%) & $33(30.3)$ & $46(41.1)$ & 0.051 & $0.5(0.2-1)$ & 0.045 \\
\hline Dominant (GC + CC vs. GG) & & & 0.091 & $0.6(0.3-1.1)$ & 0.090 \\
\hline Recessive (CC vs. GG + GC) & & & 0.095 & $0.6(0.4-1.1)$ & 0.094 \\
\hline $\mathrm{G}, \mathrm{n}(\%)$ & $107(49.1)$ & $87(38.8)$ & - & 1 & \\
\hline C, n(\%) & $111(50.9)$ & $137(61.2)$ & 0.03 & $0.7(0.4-1)$ & \\
\hline
\end{tabular}

BC $P$-value, Bonferroni corrected $P$-value

and TP53 promoter regions was significantly higher in the $\mathrm{PE}$ group, which was associated with 3.4 and 3-fold increase in PE risk respectively $(\mathrm{OR}=3.4,95 \% \mathrm{CI}=1.4-8.3 ; P=$ 0.009; $\mathrm{OR}=3,95 \% \mathrm{CI}=1.4-6.7 ; P=0.006$; respectively).

\section{Relative mRNA expression of placental P21 and TP53} genes

According to Fig. 2, the mRNA expression of the placental P21 gene was 0.2-time in PE group compared to

Table 5 Haplotype analysis of maternal P21-rs1059234 and P21rs1801270 polymorphisms and PE risk

\begin{tabular}{lllll}
\hline $\begin{array}{l}\text { Haplotype } \\
\text { rs1059234 } \\
\text { rs1801270 }\end{array}$ & PE n (\%) & Control n (\%) & P-value & OR (95\% Cl) \\
\hline CC & $398(88)$ & $397(87)$ & 0.6 & $1.1(0.7-1.6)$ \\
TA & $11(2)$ & $24(5)$ & 0.03 & $0.5(0.2-1)$ \\
CA & $22(5)$ & $29(7)$ & 0.3 & $0.7(0.4-1.3)$ \\
TC & $21(5)$ & $6(1)$ & 0.005 & $3.4(1.4-8.2)$ \\
\hline
\end{tabular}

controls $(P<0.0001)$. Level of relative mRNA expression in the placental TP53 gene was 5.6 times higher in the PE group compared to controls $(P<0.0001)$.

Association between relative mRNA expression and promoter methylation of placental P21 and TP53 genes Although placental P21 mRNA expression was higher in un-methylated promoters in comparison with methylated promoters, the difference was not significant $(P>$

Table 6 Haplotype analysis of placental P21-rs1059234 and P21rs1801270 polymorphisms and PE risk

\begin{tabular}{lllll}
\hline $\begin{array}{l}\text { Haplotype } \\
\text { rs1059234, } \\
\text { rs } 1801270\end{array}$ & PE n (\%) & Control n (\%) & P-value & OR (95\% Cl) \\
\hline CC & $188(86)$ & $188(84)$ & 0.6 & $1.2(0.7-2)$ \\
TA & $10(5)$ & $9(4)$ & 0.9 & $1(0.4-2.6)$ \\
CA & $7(3)$ & $19(8)$ & 0.03 & $0.4(0.2-0.9)$ \\
TC & $13(6)$ & $8(4)$ & 0.2 & $1.9(0.8-4.7)$ \\
\hline
\end{tabular}


Table 7 The promoter methylation status of the P21 and TP53 genes in PE women and control group

\begin{tabular}{|c|c|c|c|c|c|}
\hline & $\begin{array}{l}P E \\
(n=109)\end{array}$ & $\begin{array}{l}\text { control } \\
(n=112)\end{array}$ & OR $(95 \% \mathrm{Cl})$ & $P$-value & \\
\hline
\end{tabular}

\begin{tabular}{ccllll}
\multicolumn{7}{c}{ P21 promoter methylation } \\
UU, n (\%) & $89(81.7)$ & $105(93.8)$ & 1 & - & \\
UM, n (\%) & $17(15.6)$ & $7(6.3)$ & $2.9(1.1-7.2)$ & 0.026 & 0.021 \\
MM, n (\%) & $3(2.8)$ & $0(0)$ & - & - & \\
UM + MM vs UU, n (\%) & & $3.4(1.4-8.3)$ & 0.009 & 0.006 \\
TP53 promoter methylation & & & & \\
UU, n (\%) & $84(77.1)$ & $102(91.1)$ & 1 & - & \\
UM, n (\%) & $17(15.6)$ & $9(8)$ & $2.3(1-5.4)$ & 0.058 & 0.053 \\
MM, n (\%) & $8(7.3)$ & $1(0.9)$ & $9.7(1.2-79.2)$ & 0.034 & 0.010 \\
UM + MM vs UU, n (\%) & & $3(1.4-6.7)$ & 0.006 & 0.004 \\
\hline
\end{tabular}

U: Unmethylated: M: Methylated; BC P-value, Bonferroni corrected P-value

0.05). The TP53 mRNA expression was higher in the placental TP53 methylated promoters, compared to unmethylated promoters; nonetheless, the difference was marginally not significant $(P=0.06)$ (Fig. 3$)$.

\section{Association between relative mRNA expression and placental P21 and TP531 polymorphisms}

No relationship was found between P21-rs1059234 polymorphism and relative mRNA expression of P21. The relative mRNA expression of $P 21$ gene was 2.4 times higher in rs $1801270 \mathrm{CA}$ genotype, compared to AA genotype $(P=0.04)$. On the other hand, the relative mRNA expression of placental TP53 gene showed no significant difference between rs1042522 genotypes $(P>0.05)$ (Fig. 4).

As shown in tables, all statistical findings remained significant after Bonferroni correction.

\section{Discussion}

Apoptosis is the process of programmed cell death, occurring when the cells are exposed to physiological, pathogenic, or cytotoxic stimuli [27]. It also affects the life cycle of trophoblasts in the placenta [28]. Many proteins are involved in the regulation of apoptotic process, such as P53 and P21. It is well-established that the etiology of PE is related to the placenta, as the clinical symptoms are relieved after placental delivery [5]. Tomas et al. demonstrated that trophoblast apoptosis was significantly higher in PE placentas, compared with controls. Moreover, an increase in placental apoptosis and syncytial knot formation has been reported in PE pregnancies. Therefore, amplified trophoblast turnover might result in the excessive release of trophoblast into maternal circulation, producing PE symptoms [29]. P53 also contributes to the regulation of cell apoptosis [30]. According to previous studies, upregulation of P53 induces apoptosis and suppresses endothelial cell proliferation in PE pregnancies. This condition of endothelial cells in fetal and maternal circulation may contribute to the pathogenesis of PE [31]. Several mechanisms, including hypoxia and oxidative stress, can explain p53 stimulation in PE. P53 may contribute to PE at several cellular dysfunction levels,resulting in apoptosis and exaggerated autophagy [8]. Previous studies demonstrated that in complicated pregnancies, upregulation of p53 pathway leads to the buildup of downstream cell-free target genes (e.g., P21) in maternal circulation. In addition, plasma p21 mRNA expression can be indicative of complicated pregnancies [32, 33]. This case-control study compared the frequency of polymorphic variants in apoptotic genes of maternal blood and placenta of PE and normotensive pregnant women in Southeast of Iran. We found that maternal and placental P21-rs1801270 CA genotype was associated with a decreased PE risk (0.3 and 0.4-fold respectively). However, no association was found between maternal/placental P21-rs1059234 polymorphism and PE risk in the dominant, recessive, or allelic models. The maternal TP53-rs1042522 polymorphism was associated with the reduced risk of PE in the dominant, recessive, and allelic models. The significant association between
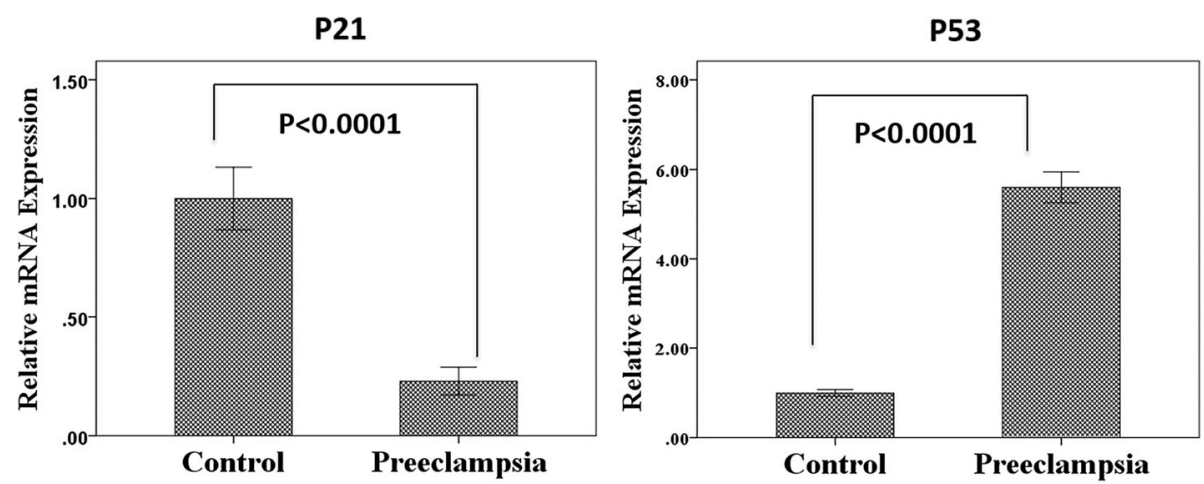

Fig. 2 The relative mRNA expression of P21 and TP53 genes in PE women and controls 

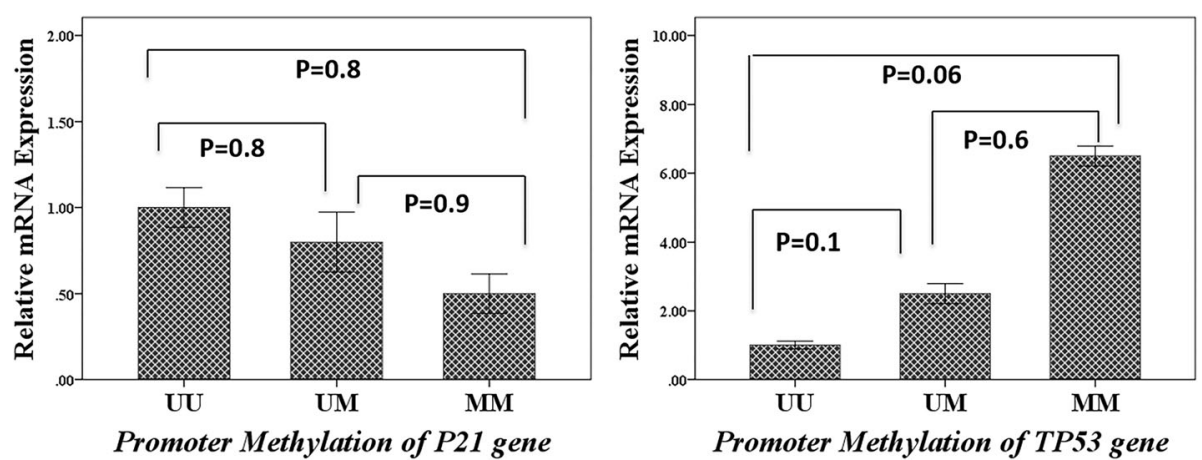

Fig. 3 The association of relative mRNA expression and promoter methylation of placental P21 and TP53 genes

placental TP53-rs1042522 and reduction in PE risk was observed in allelic model but not in dominant and recessive models. Based on the haplotype analysis, the maternal P21 $\mathrm{T}_{\mathrm{rs} 1059234} \mathrm{C}_{\mathrm{rs} 1801270}$ haplotype was associated with 3.4-fold increase in PE risk, However the maternal P21 $\mathrm{T}_{\text {rs1059234 }} \mathrm{A}_{\mathrm{rs} 1801270}$ haplotype and placental $\mathrm{C}_{\mathrm{rs} 1059234 \mathrm{C}} \mathrm{A}$ rs1801270 haplotype led to 0.5 and 0.4 -fold decrease in PE risk, respectively. Although some studies have highlighted the importance of polymorphic variants in apoptotic pathways during pregnancy, no study has yet examined the effects of maternal and placental P21rs1059234 and P21-rs1801270 polymorphisms on the risk of PE. In addition, no study has investigated the placental TP53-rs1042522 polymorphism as a possible risk factor for PE. With respect to the TP53 gene, some studies have reported a relationship between TP53 gene SNPs and idiopathic recurrent miscarriage [34], recurrent pregnancy loss [35], uterine leiomyoma susceptibility [12], and endometriosis-associated infertility [36]. Moreover, Busatto et al. analyzed the TP53-rs1042522 gene polymorphism in 99 healthy pregnant and $119 \mathrm{PE}$ women in Brazil. Inconsistent with our observations, the case and control groups were not significantly different [17]. The association between $P 21$ polymorphisms and susceptibility to uterine leiomyoma [14], late-onset Alzheimer's disease [37], and cancer [38] has been investigated in the literature; however, the effects of $P 21$ polymorphisms on diseases are controversial. In addition, we found that level of relative placental mRNA expression in TP53 gene was 5.6 times higher in the PE group $(P<0.0001)$, however, TP53 mRNA expression showed no significant difference between rs1042522 genotypes. In the placental $P 21$ gene, the relative mRNA expression was significantly reduced in the PE group, compared to controls $(\mathrm{P}<0.0001)$. The mRNA expression of rs $1801270 \mathrm{CA}$ genotype was 2.4 times higher than that of AA genotype. Hyper-methylation of P21 and TP53 genes (UM + MM) in the promoter region was associated with a 3.4- fold and 3-fold increase in PE risk, respectively, however, no association was found between P21 and TP53 mRNA expression and promoter methylation. In this regard, Gao et al., after culturing human umbilical cord vein endothelial cells (HUVECs) from normal and PE pregnancies, evaluated cell growth. To identify the distribution of cell cycle and apoptosis, flowcytometric assessment was also performed. Based on the findings, cell growth was majorly repressed, while G1 arrest and apoptosis was increased in cultured HUVECs from $\mathrm{PE}$ pregnancies compared to normotensive pregnancies (controls). Since P53 protein was upregulated in HUVECs from PE pregnancies, G1 arrest, followed by P21 upregulation and downregulation of cyclin E was induced [39]. Sharp et al. found that the protein expression of p53 and p21 was increased significantly in the
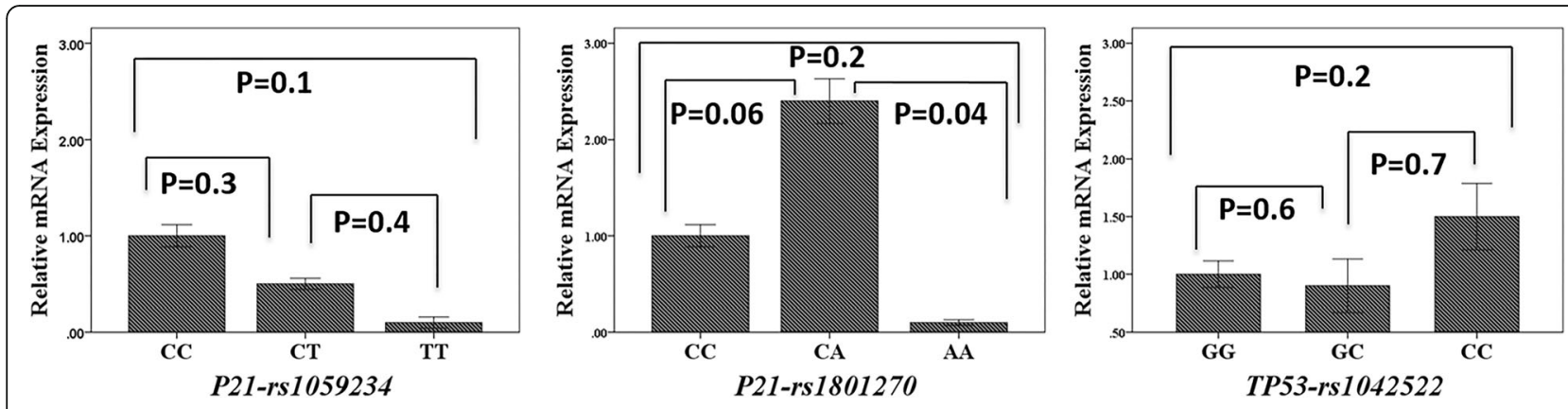

Fig. 4 The association of relative mRNA expression and placental P21-rs1059234, P21-rs1801270 and TP53-rs1042522 polymorphisms 
villous trophoblasts of PE-affected placental villi [8]. However, no significant change in the expression of apoptotic genes, such as p53, was observed in a study conducted by Mendilcioglu et al. [40]. Londero et al. reported a change in the immunohistochemical expression of cellular senescence and DNA damage markers, including $T p 53$ and $p 21$ in the trophoblast and the placentas of PE [41]. Ashur-Fabian et al. showed the higher prevalence of cell-free plasma expressions of hif1 $\alpha$ and $P 21$ genes in pregnancies affected by hypoxia and/or intrauterine growth restriction [33]. In addition, Davies et al. recently showed that P21 in early-onset PE placentas was significantly higher than that of controls [42]. Although the association between P21 and TP53 promoter methylation and PE has not been examined, several studies have confirmed the effect of TP53 and P21 promoter methylation on various diseases such as cancer [24, 43-45]. Indeed, some studies have confirmed the relationship between methylation of several genes and PE susceptibility $[18,46,47]$.

\section{Conclusions}

In conclusion, our results suggest that TP53 and P21 polymorphisms could affect the risk of PE. The decreased risk of PE was associated with P21-rs1801270 and TP53-rs1042522 polymorphisms. The risk of PE increased 3.4 times in the presence of maternal P21 $\mathrm{T}_{\mathrm{rs} 1059234} \mathrm{C}_{\mathrm{rs} 1801270}$ haplotype and decreased to 0.5 and 0.4 -fold in the presence of maternal $\mathrm{T}_{\mathrm{rs} 1059234} \mathrm{~A}_{\mathrm{rs} 1801270}$ and placental $\mathrm{C}_{\mathrm{rs} 1059234 \mathrm{C}} \mathrm{A}$ rs1801270 haplotypes, respectively. P21-rs1801270 was associated with decreased P21 mRNA expression. In the promoter region, hypermethylation of P21 and TP53 genes increased the risk of PE. However, there was no relationship between P21/ TP53 mRNA expression and promoter methylation. Therefore, studies in different ethnic populations with a larger sample size should be performed to validate these findings and elucidate the molecular mechanisms of apoptosis involved in the development of PE.

\section{Supplementary information}

Supplementary information accompanies this paper at https://doi.org/10. 1186/s12929-019-0586-x

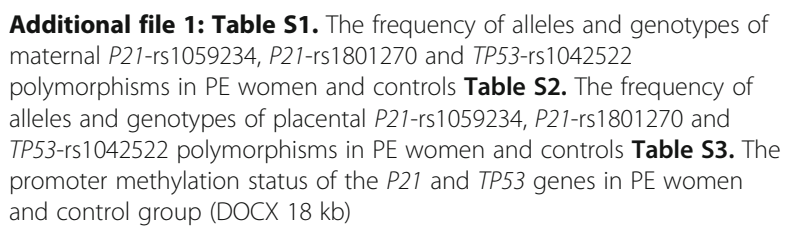

\section{Abbreviations}

DBP: Diastolic blood pressure; MSP: Methylation specific PCR;

PCR: Polymerase chain reaction; PE: Preeclampsia; RFLP: Restriction fragment length polymorphism; SBP: systolic blood pressure

\section{Acknowledgements}

We express our gratitude to the Cellular and Molecular Research Center and Department of Clinical Biochemistry of Zahedan University of Medical Sciences.

\section{Authors' contributions}

MHS Project development, Data collection, molecular analysis, Manuscript writing/ editing, LK Project development, Manuscript editing, BT Data collection, Manuscript editing, MM, experimental analysis, Manuscript editing, SS Project development, Data analysis and interpretation, Manuscript writing/ editing. All authors read and approved the final manuscript.

\section{Funding}

Not applicable (no funding was received).

\section{Availability of data and materials}

All supporting data have been shown in the manuscript.

\section{Ethics approval and consent to participate}

The written informed consents were collected, and the Ethics Committee of Zahedan University of Medical Sciences provided an ethical approval for conducting this study, which was in compliance with Declaration of Helsinki.

\section{Consent for publication}

The written informed consents were obtained from the participants for publication of their individual details (the demographic data presented in Table 2) in this manuscript. The authors declare that this article is original, has never been published before, and has not been submitted to other journals.

\section{Competing interests}

The authors disclose that they have no competing interests.

\section{Author details}

${ }^{1}$ Genetic of Non-Communicable Disease Research Center, Zahedan University of Medical Sciences, Zahedan, Iran. ${ }^{2}$ Department of Biology, Arsanjan Branch, Islamic Azad University, Arsanjan, Iran. ${ }^{3}$ Department of Obstetrics and Gynecology, School of Medicine, Zahedan University of Medical Sciences, Zahedan, Iran. ${ }^{4}$ Physiology Research Center, Institute of Basic and Clinical Physiology Sciences, Kerman University of Medical Sciences, Kerman, Iran ${ }^{5}$ Department of Clinical Biochemistry, School of Medicine, Zahedan University of Medical Sciences, Zahedan, Iran. ${ }^{6}$ Cellular and Molecular Research Center, Zahedan University of Medical Sciences, Zahedan, Iran.

Received: 19 January 2019 Accepted: 24 October 2019

Published online: 08 November 2019

\section{References}

1. Mohammadpour-Gharehbagh A, Salimi S, Keshavarzi F, Saeidian F, Mousavi M, Teimoori B, Esmaeilipour M, Mokhtari M. Genetic variants in 3'-UTRs of MTHFR in the pregnancies complicated with preeclampsia and bioinformatics analysis. J Cell Biochem. 2018;119:773-81.

2. Mohammadpour-Gharehbagh A, Teimoori B, Narooei-nejad M, Mehrabani M, Saravani R, Salimi S. The association of the placental MTHFR 3'-UTR polymorphisms, promoter methylation, and MTHFR expression with preeclampsia. J Cell Biochem. 2018;119:1346-54.

3. Liu Y, Ma Y. Promoter methylation status of WNT2 in placenta from patients with preeclampsia. Medical science monitor: international medical journal of experimental and clinical research. 2017;23:5294.

4. Xuan J, Jing Z, Yuanfang Z, Xiaoju H, Pei L, Guiyin J, Yu Z. Comprehensive analysis of DNA methylation and gene expression of placental tissue in preeclampsia patients. Hypertension in pregnancy. 2016;35:129-38.

5. Harati-Sadegh M, Kohan L, Teimoori B, Mehrabani M, Salimi S. The association of the placental hypoxia-inducible factor1-a polymorphisms and HIF1-a mRNA expression with preeclampsia. Placenta. 2018;67:31-7.

6. Can M, Guven B, Bektas S, Arikan I. Oxidative stress and apoptosis in preeclampsia. Tissue Cell. 2014;46:477-81.

7. Timofeeva AV, Gusar VA, Kan NE, Prozorovskaya KN, Karapetyan AO, Bayev OR, Chagovets W, Kliver SF, lakovishina DY, Frankevich VE. Identification of potential early biomarkers of preeclampsia. Placenta. 2018;61:61-71. 
8. Sharp AN, Heazell AE, Baczyk D, Dunk CE, Lacey HA, Jones CJ, Perkins JE, Baker PN, Crocker IP. Preeclampsia is associated with alterations in the p53pathway in villous trophoblast. PLoS One. 2014;9:e87621.

9. Velez AMA, Howard MS. Tumor-suppressor genes, cell cycle regulatory checkpoints, and the skin. N Am J Med Sci. 2015;7:176.

10. Fischer M. Census and evaluation of p53 target genes. Oncogene. 2017;36:3943.

11. Levy R, Smith SD, Yusuf K, Huettner PC, Kraus FT, Sadovsky Y, Nelson DM. Trophoblast apoptosis from pregnancies complicated by fetal growth restriction is associated with enhanced p53 expression. Am J Obstet Gynecol. 2002;186:1056-61.

12. Yaghmaei M, Salimi S, Namazi L, Farajian-Mashhadi F. Association of XRCC1 Arg399GIn and Tp53 Arg72Pro polymorphisms and increased risk of uterine leiomyoma-a case-control study. Genet Mol Biol. 2015;38:444-9.

13. Lim S, Kaldis P. Cdks, cyclins and CKIs: roles beyond cell cycle regulation. Development. 2013;140:3079-93.

14. Salimi S, Hajizadeh A, Yaghmaei M, Rezaie S, Shahrakypour M, Teimoori B, Parache M, Naghavi A, Mokhtari M. The effects of p21 gene C98A polymorphism on development of uterine leiomyoma in southeast Iranian women. Tumor Biol. 2016;37:12497-502.

15. Pendeloski KP, Lobo TF, Torloni MR, Mattar R, Daher S: Fas-FasL genotype and phenotype in preeclampsia.

16. Orlando IC, Tanaka SCSV, Balarin MAS, da Silva SR, Pissetti CW. CASPASE-8 gene polymorphisms (rs13416436 and rs2037815) are not associated with preeclampsia development in Brazilian women. J Matern Fetal Neonatal Med. 2018;31:289-93.

17. Busatto M, Boquett J. Polymorphisms of the apoptotic genes TP53 and MDM2 and preeclampsia development. JFIV Reprod Med Genet. 2014;3(1).

18. Rezaei M, Eskandari F, Mohammadpour-Gharehbagh A, Harati-Sadegh M, Teimoori B, Salimi S. Hypomethylation of the miRNA-34a gene promoter is associated with severe preeclampsia. Clin Exp Hypertens. 2018:1-5.

19. Lim YC, Li J, Ni Y, Liang Q, Zhang J, Yeo GS, Lyu J, Jin S, Ding C. A complex association between DNA methylation and gene expression in human placenta at first and third trimesters. PLoS One. 2017;12:e0181155.

20. Lu L, Hou Z, Li L, Yang Y, Wang X, Zhang B, Ren M, Zhao D, Miao Z, Yu L. Methylation pattern of $\mathrm{H} 19$ exon 1 is closely related to preeclampsia and trophoblast abnormalities. Int J Mol Med. 2014;34:765-71.

21. Salimi S, Mohammadpour-Gharehbagh A, Rezaei M, Sajadian M, Teimoori B, Yazdi A, Mokhtari M, Yaghmaei M. The MDM2 promoter T309G polymorphism was associated with preeclampsia susceptibility. J Assist Reprod Genet. 2017:1-6.

22. Brakensiek K, Länger $F$, Kreipe $H$, Lehmann U. Absence of p21CIP1, p27KIP1 and p57KIP2 methylation in MDS and AML. Leuk Res. 2005;29:1357-60

23. Park H-J, Yu E, Shim Y-H. DNA methyltransferase expression and DNA hypermethylation in human hepatocellular carcinoma. Cancer Lett. 2006;233:271-8

24. Teramen H, Tsukuda K, Tanaka N, Ueno T, Kubo T, Ando M, Soh J, Asano H, Pass HI, Toyooka S. Aberrant methylation of p 21 gene in lung Cancer and malignant pleural mesothelioma. Acta Med Okayama. 2011;65:179-84.

25. Liu R, Yin L, Pu Y. Association between gene expression of metabolizing enzymes and esophageal squamous cell carcinomas in China. Genet Test Mol Biomarkers. 2012;16:1211-7.

26. Shen J, Li Z, Chen J, Song Z, Zhou Z, Shi Y. SHEsisPlus, a toolset for genetic studies on polyploid species. Sci Rep. 2016;6:24095

27. Elmore S. Apoptosis: a review of programmed cell death. Toxicol Pathol. 2007;35:495-516.

28. Scifres $\mathrm{CM}$, Nelson DM. Intrauterine growth restriction, human placental development and trophoblast cell death. J Physiol. 2009;587:3453-8.

29. Tomas S, Prusac IK, Roje D, Tadin I. Trophoblast apoptosis in placentas from pregnancies complicated by preeclampsia. Gynecol Obstet Investig. 2011;71:250-5.

30. Deng M, Chen P, Liu F, Fu S, Tang H, Fu Y, Xiong Z, Hui S, Ji W, Zhang X. The p53-Bak apoptotic signaling axis plays an essential role in regulating differentiation of the ocular lens. Curr Mol Med. 2012;12:901-16.

31. Gao Q, Zhu X, Chen J, Mao C, Zhang L, Xu Z. Upregulation of P53 promoted G1arrest and apoptosis in human umbilical cord vein endothelial cells from preeclampsia. J Hypertens. 2016;34:1380

32. Heazell A, Lacey H, Jones C, Huppertz B, Baker P, Crocker I. Effects of oxygen on cell turnover and expression of regulators of apoptosis in human placental trophoblast. Placenta. 2008;29:175-86.
33. Ashur-Fabian O, Yerushalmi GM, Mazaki-Tovi S, Steinberg DM, Goldshtein I, Yackobovitch-Gavan M, Schiff E, Amariglio N, Rechavi G. Cell free expression of hif1a and p21 in maternal peripheral blood as a marker for preeclampsia and fetal growth restriction. PLoS One. 2012;7:e37273.

34. Pietrowski D, Bettendorf H, Riener E-K, Keck C, Hefler LA, Huber JC, Tempfer C. Recurrent pregnancy failure is associated with a polymorphism in the p53 tumour suppressor gene. Hum Reprod. 2005;20:848-51.

35. Razieh Dehghani F, Nasrin G, Maryam Ayazi R, Nasim T. Association of p53 polymorphism with ICSI/IVF failure and recurrent pregnancy loss. Aust N Z J Obstet Gynaecol. 2009;49:216-9.

36. Paskulin D, Cunha-Filho J, Souza C, Bortolini M, Hainaut P, Ashton-Prolla P. TP53 PIN3 and PEX4 polymorphisms and infertility associated with endometriosis or with post-in vitro fertilization implantation failure. Cell Death Dis. 2012;3:e392.

37. Scacchi R, Gambina G, Moretto G, Corbo R. P21 gene variation and lateonset Alzheimer's disease in the Italian population. Dement Geriatr Cogn Disord. 2013;35:51-7.

38. Huang Y-S, Fan Q-Q, Li C, Nie M, Quan H-Y, Wang L. Quantitative assessment the relationship between p21 rs1059234 polymorphism and cancer risk. Asian Pac J Cancer Prev APJCP. 2015;16:4435-8.

39. Gao Q, Zhu X, Chen J, Mao C, Zhang L, Xu Z. Upregulation of P53 promoted G1 arrest and apoptosis in human umbilical cord vein endothelial cells from preeclampsia. J Hypertens. 2016;34:1380-8.

40. Mendilcioglu I, Karaveli S, Erdogan G, Simsek M, Taskin O, Ozekinci M. Apoptosis and expression of Bcl-2, Bax, p53, caspase-3, and Fas, Fas ligand in placentas complicated by preeclampsia. Clinical and experimental obstetrics and gynecology. 2011;38:38-42.

41. Londero AP, Orsaria M, Marzinotto S, Grassi T, Fruscalzo A, Calcagno A, Bertozzi S, Nardini N, Stella E, Lellé RJ. Placental aging and oxidation damage in a tissue micro-array model: an immunohistochemistry study. Histochem Cell Biol. 2016;146:191-204.

42. Cindrova-Davies T, Fogarty NM, Jones CJ, Kingdom J, Burton GJ. Evidence of oxidative stress-induced senescence in mature, post-mature and pathological human placentas. Placenta. 2018;68:15-22.

43. Chmelarova M, Krepinska E, Spacek J, Laco J, Beranek M, Palicka V. Methylation in the p53 promoter in epithelial ovarian cancer. Clin Trans Oncol. 2013:15:160-3.

44. Torng P-L, Lin C-W, Chan MW, Yang H-W, Huang S-C, Lin C-T. Promoter methylation of IGFBP-3 and p53 expression in ovarian endometrioid carcinoma. Mol Cancer. 2009;8:1.

45. Moreira PR, Guimarães MM, Guimarães ALS, Diniz MG, Gomes CC, Brito JAR, Gomez RS. Methylation of P16, P21, P27, RB1 and P53 genes in odontogenic keratocysts. Journal of oral pathology and medicine. 2009;38:99-103.

46. Yeung KR, Chiu CL, Pidsley R, Makris A, Hennessy A, Lind JM. DNA methylation profiles in preeclampsia and healthy control placentas. Am J Phys Heart Circ Phys. 2016;310:H1295-303.

47. Sundrani DP, Reddy US, Joshi AA, Mehendale SS, Chavan-Gautam PM, Hardikar AA, Chandak GR, Joshi SR. Differential placental methylation and expression of VEGF, FLT-1 and KDR genes in human term and preterm preeclampsia. Clin Epigenetics. 2013;5:6.

\section{Publisher's Note}

Springer Nature remains neutral with regard to jurisdictional claims in published maps and institutional affiliations.

Ready to submit your research? Choose BMC and benefit from:

- fast, convenient online submission

- thorough peer review by experienced researchers in your field

- rapid publication on acceptance

- support for research data, including large and complex data types

- gold Open Access which fosters wider collaboration and increased citations

- maximum visibility for your research: over $100 \mathrm{M}$ website views per year

At $\mathrm{BMC}$, research is always in progress.

Learn more biomedcentral.com/submissions 